To Maega | Jurnal Pengabdian Masyarakat

Februari 2022, Vol.5, No.1, hal, 44-53

$\operatorname{ISSN}(P): 2622-6332 ; \operatorname{ISSN}(E): 2622-6340$

http://www.ojs.unanda.ac.id/index.php/tomaega

\title{
Pemanfaatan Limbah Sabut Kelapa sebagai Media Tanam Hidroponik dalam Mendukung Pemenuhan Gizi dan Pendapatan Kelompok Tani Posi Lita di Masa Pandemi Covid-
} 19

\author{
Dwi Ahrisa Putri 1*, Arman Amran 1, Kurniati ${ }^{2}$ \\ ${ }_{1}^{1}$ Program Studi Agribisnis, Fakultas Pertanian dan Kehutanan, Universitas Sulawesi Barat \\ 2 Program Studi Agroekoteknologi, Fakultas Pertanian dan Kehutanan, Universitas Sulawesi \\ Barat \\ *Correspondent Email: dwiahrisaputri@unsulbar.ac.id
}

Article History:

Received: 01-11-2021; Received in Revised: 13-11-2021; Accepted: 16-12-2021

DOI: http://dx.doi.org/10.35914/tomaega.v5i1.944

\begin{abstract}
Abstrak
Desa Tandung merupakan salah satu desa di Kecamatan Tinambung, Kabupaten Polewali Mandar yang mengalami kendala tidak adanya sarana pengolahan limbah sabut kelapa yang ramah lingkungan, masyarakat setempat hanya memanfaatkan sabut kelapa untuk media pembakaran sebagai pengganti arang. Kondisi ini mengakibatkan penumpukan limbah sabut kelapa di sekitar rumah penduduk dan kebun petani, padahal sesungguhnya limbah ini dapat dikelola secara berkelanjutan sehingga dapat dimanfaatkan kembali dan juga dapat memberikan nilai tambah secara ekonomi. Beberapa keunggulan dari sabut kelapa adalah memiliki daya serap air tujuh kali lebih tinggi dibandingkan tanah, meningkatkan sirkulasi oksigen bagi akar tanaman, mengandung unsur hara, kalium, fosfor, nitrogen, kalsium, besi, magnesium, mangan, boron, dan seng. Metode pendekatan yang digunakan pada pengabdian masyarakat ini adalah pendekatan PRA (Participatory Rural Appraisal), dimana melibatkan kelompok tani sebagai mitra yang akan melakukan proses kegiatan dengan didampingi oleh tim dosen sebagai fasilitator pelatihan. Dengan metode tersebut, memungkinkan masyarakat desa untuk saling berbagi, meningkatkan dan menganalisis pengetahuan mereka tentang kondisi dan kehidupan desa, membuat rencana dan bertindak. Kegiatan pengabdian ini memberikan solusi dari permasalahan mitra, yaitu dengan adanya pelatihan hidroponik dan pendampingan kelompok masyarakat tani Posi Lita, masyarakat menjadi tahu dan mengenal olahan sabut kelapa menjadi cocopeat sebagai media tanam hidroponik. Selain mampu meningkatkan pendapatan juga dapat memenuhi kebutuhan gizi dari sayuran organik yang dibudidayakan serta menciptakan masyarakat yang sadar lingkungan melalui limbah yang dapat diolah lebih optimal.
\end{abstract}

Kata Kunci: limbah, sabut kelapa, hidroponik, gizi, pendapatan.

\begin{abstract}
Tandung Village is one of the villages in Tinambung Subdistrict, Polewali Mandar Regency which is experiencing obstacles in the absence of environmentally friendly coconut coir waste treatment facilities, the local community only uses coconut coir for burning media as a substitute for charcoal. This condition results stacking of coconut coir waste around people's houses and farmers' gardens, while in fact this waste can be managed sustainably so that it can be reused and also provided added value
\end{abstract}


economically. Some of the advantages of coconut coir is that it has a water absorption seven times higher than soil, increases oxygen circulation for plant roots, contains nutrients, potassium, phosphorus, nitrogen, calcium, iron, magnesium, manganese, boron, and zinc. The approach method used in this community service is the PRA (Participatory Rural Appraisal) approach, which involves the farmer group as partners who will carry out the activity process accompanied by a team of lecturers as training facilitators. By this method, it allows villagers to share, improve and analyze their knowledge of village conditions and life, make plans and act. This community service provides solutions to partner problems, namely with hydroponic training and mentoring of Posi Lita farmer groups, they become aware and know how to process coconut coir into cocopeat as a hydroponic planting medium. In addition to, being able to increase income can also fulfill the nutritional needs of organic vegetables that are cultivated and create an environmentally conscious society through waste that can be processed more optimally.

Keywords: waste, coconut coir, hydroponics, nutrition, income.

\section{Pendahuluan}

Komoditi unggulan di Kabupaten Polewali Mandar pada bidang perkebunan salah satunya adalah penghasil kelapa dalam maupun kelapa hibrida. Akan tetapi pemanfaatan yang dilakukan oleh masyarakat setempat belum dilakukan secara maksimal pada seluruh bagian dari kelapa tersebut, terutama pada sabut kelapa yang tidak diolah kembali dan dibuang begitu saja atau hanya dimanfaatkan sebagai pembakar bahan makanan saja. Sejalan dengan pendapat Amin et al (2014) bahwa pengolahan buah kelapa umumnya masih terfokus pada pengolahan hasil daging buah sebagai hasil utama, sedang-kan pengolahan bagian lain dari buah kelapa masih sangat kurang.

Agustian, et al (2003) menyatakan bahwa sabut kelapa merupakan bagian yang cukup besar dari buah kelapa, yaitu $35 \%$ dari berat keseluruhan buah. Sabut kelapa terdiri dari serat dan gabus yang menghubungkan satu serat dengan serat lainnya. Setiap butir kelapa rata-rata mengandung serat 525 gram (75\% dari sabut) dan gabus 175 gram (25\% dari sabut) Limbah dari komoditi unggul ini sangat disayangkan jika tidak dimanfaatkan dengan baik dan tidak menambah penghasilan masyarakat, sementara peranannya juga cukup besar sama halnya dengan bagian kelapa yang lainnya (Indahyani, 2011).

Demikian dengan penelitian Simanjuntak dan Heddy (2018) bahwa media tanam campuran tanah dan cocopeat dapat meningkatkan pertumbuhan tanaman horenso. Tinggi tanaman sebesar $29.51 \%$ dan jumlah daun sebesar $21.60 \%$, dan luas daun sebesar 23.01\%.Campuran media tanam tanah dan cocopeat serta konsentrasi pupuk cair kotoran kelinci $80 \mathrm{ml} \mathrm{liter}^{-1}$ dapat meningkatkan hasil berat konsumsi tangkai daun $66.68 \%$ dan berat konsumsi daun $71.91 \%$.

Kelompok Tani Posi Lita merupakan kelompok tani yang mana anggotanya ikut juga merasakan imbas dari adanya wabah pandemi Covid-19 (corona virus), mengakibatkan setiap kabupaten melakukan lockdown sehingga terjadilah penurunan pendapatan di masing-masing wilayah kerja. Akibat adanya 
pandemi Covid-19 ini banyak masyarakat yang mengalami pemberhentian kerja atau pengurangan karyawan dari tempat kerja sebelumnya. Hal lain juga terjadi, ketika harga kelapa dan pembelian kelapa dalam mengalami penurunan, secara otomatis juga pendapatan masyarakat mengalami penurunan secara signifikan tetapi pengeluaran dalam setiap bulannya tetap ada dan justru bertambah, terutama kebutuhan tiap hari keluarga dalam hal ini kebutuhan akan konsumsi bahan makanan. Sementara itu, salah satu limbah yang dihasilkan dari produksi kelapa adalah sabut kelapa yang semakin menumpuk dan tidak begitu laku ketika dijual.

Christina (2019) menyatakan bahwa perkembangan penduduk yang tidak dapat diprediksi setiap tahunnya mengakibatkan lahan penduduk yang semakin sempit dan padatnya penduduk suatu wilayah dapat menyebabkan minimnya lahan pemukiman warga. Hal ini diperparah dengan situasi pandemi yang memungkinkan masyarakat untuk lebih sadar akan ketersediaan bahan pangan yang dapat diusahakan sendiri di lahan pekarangan yang terbatas menjadikan budidaya sayur mayur di pekarangan rumah memiliki peluang yang kecil jika tidak menggunakan metode-metode tertentu.

Berdasarkan keresahan yang dialami oleh masyarakat di Desa Tandung maka Kelompok Tani Posi Lita di bawah bimbingan dosen dari Universitas Sulawesi Barat, ingin memanfaatkan sabut kelapa yang akan dijadikan sebagai media tanam hidroponik bagi masyarakat setempat serta menambah penghasilan dari penjualan sayur organik yang mereka produksi sendiri. Kegiatan ini bertujuan untuk meningkatkan pengetahuan melalui pemberdayaan kelompok tani untuk meningkatkan penghasilan dan tetap memenuhi kebutuhan gizi masyarakat melalui pemanfaatan limbah sabut kelapa untuk tanaman sayuran hidroponik di Kabupaten Polewali Mandar.

\section{Metode}

Kegiatan pengabdian ini dilakukan sejak 17 Juli sampai 17 Oktober 2021 di Desa Tandung, Kecamatan Tinambung, Kabupaten Polewali Mandar. Kelompok Tani Posi Lita merupakan mitra sasaran yang beranggotakan 25 orang petani yang diketuai oleh Bapak Israil. Metode pendekatan yang digunakan pada pengabdian masyarakat ini adalah pendekatan PRA (Participatory Rural Appraisal), dimana melibatkan kelompok tani sebagai mitra yang akan melakukan proses kegiatan. Metode pendekatan PRA memungkinkan masyarakat desa untuk saling berbagi, meningkatkan dan menganalisis pengetahuan mereka tentang kondisi dan kehidupan desa, membuat rencana dan bertindak (Balitbang, 2013).

Alat-alat yang digunakan dalam kegiatan pengabdian ini adalah : botol bekas $600 \mathrm{~mL}$ atau $1,5 \mathrm{~L}$, cutter atau gunting, hand spayer, kain flannel, label nutrisi, suntik, plastik hitam atau yang berwarna gelap dan wadah/nampan penyemaian. Bahan-bahan yang digunakan yaitu air mineral, benih selada, sawi hijau, kangkong. nutrisi hidroponik AB-MIX dan serbuk sabut kelapa (cocopeat). Tahapan pelaksanaan dalam pengabdian masyarakat ini yaitu: 
1. Sosialisasi

Kegiatan ini bertujuan untuk menjelaskan semua yang berkaitan dengan pemanfaatan limbah sabut kelapa sebagai media tanam hidroponik. Selain sebagai media tanam, sabut kelapa juga memiliki peranan dalam menyediakan unsur hara yang dibutuhkan oleh tanaman sehingga akan meminimalisir penggunaan pupuk sintetis, dan juga memiliki kemampuan menyerap dan menyimpan air berkali lipat dibandingkan tanah sehingga mampu beradaptasi walaupun pada musim kemarau.

2. Pelatihan

Kegiatan ini diawali dengan persiapan lahan pekarangan yang cukup luas sehingga dapat menanam berbagai jenis tanaman sayuran. Jenis tanaman sayur yang akan ditaman antara lain, bayam, kangkung, seledri, selada, sawi hijau, cabai dan tomat. Adapun tahapan dalam persiapan ini antara lain:

- Persiapan lahan pekarangan

- Persiapan media tanam sabut kelapa (cocopeat)

- Pemasangan instalasi hidroponik

- Penanaman

- Panen

3. Pembinaan petani.

Selain memberikan sosialisai dan praktik pemanfaatan limbah sabut kelapa sebagai media tanam hidroponik, bentuk pembinaan yang akan dilakukan dengan petani mitra adalah melakukan pendampingan selama dua bulan untuk melihat tingkat efisiensi dari pemenuhan kebutuhan gizi keluarga secara mandiri dan kemajuan penjualan sayur organik tersebut guna menambah pendapatan keluarga.

\section{Hasil dan Pembahasan}

Tahapan kegiatan yang dilakukan dalam kegiatan pengabdian di Desa Tandung, Kecamatan Tinambung, Kabupaten Polewali Mandar, yaitu sebagai berikut :

1. Sosialisasi pemanfaatan sabut kelapa sebagai media tanam hidroponik.

Sosialisasi dilaksanakan pada 17 Juli 2021 di pekarangan rumah Ketua Kelompok Tani Posi Lita di Desa Tandung, Kecamatan Tinambung, Kabupaten Polewali Mandar. Kegiatan sosialisasi dihadiri oleh 15 orang perwakilan kelompok tani dikarenakan pandemi Covid-19 yang membatasi kegiatan berkumpul warga dan hal tersebut sesuai instruksi Kepala Desa. Tim dosen pengabdi memberikan penjelasan materi mengenai hidroponik disertai demo penggunaan alat dan bahan yang digunakan untuk isntalasai.

Sosialisasi berjalan baik dan lancar ditandai dengan antusiasme kelompok tani dan masyarakat sekitar bertanya dan mempraktekkan penggunaan alat dan bahan yang telah disedikan. Mahasiswa pendamping 
juga turut hadir untuk membantu proses sosialisasi dan demo penggunaan alat dan bahan.

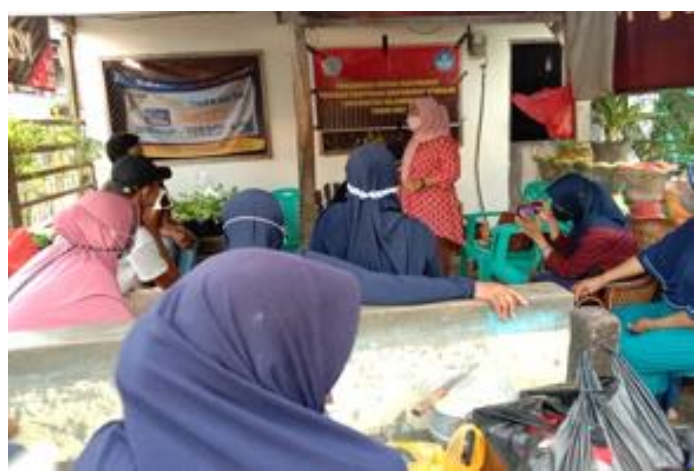

Gambar 2. Sosialisasi dan Pelatihan Hidroponik

Penjelasan tim dosen sejalan dengan Istomo dan Valentino (2012) menyatakan bahwa media serbuk sabut kelapa (cocopeat) pada dasarnya memiliki kemampuan mengikat dan menyimpan air yang sangat kuat. Serbuk sabut kelapa (cocopeat) merupakan media yang memiliki kapasitas menahan air cukup tinggi. Media cocopeat memiliki pori mikro yang mampu menghambat gerakan air lebih besar sehingga menyebabkan ketersediaan air lebih tinggi Kemampuan media untuk menyimpan air dan menyediakan unsur hara akan berpengaruh pada pertumbuhan tanaman. Media tanaman yang berbeda akan menghasilkan pertumbuhan tanaman yang berbeda.

Pemilihan media tumbuh dalam sistem hidroponik harus memenuhi persyaratan untuk ketersediaan air dan udara bagi pertumbuhan tanaman. Media tumbuh yang ideal untuk hidroponik antara lain dapat menopang pertumbuhan tanaman, memiliki pori untuk aerasi, tidak menyumbat instalasi hidroponik, dan tidak mempengaruhi larutan nutrisi. Media tidak berfungsi menyediakan nutrisi dan harus bersifat lembam (Orsini et al, 2012).

2. Persiapan lahan pekarangan dan pemasangan instalasi hidroponik sederhana Ada beberapa tahapan penyiapan perangkat hidroponik sebelum memulai proses penyemaian :

a. Penyiapan wadah botol

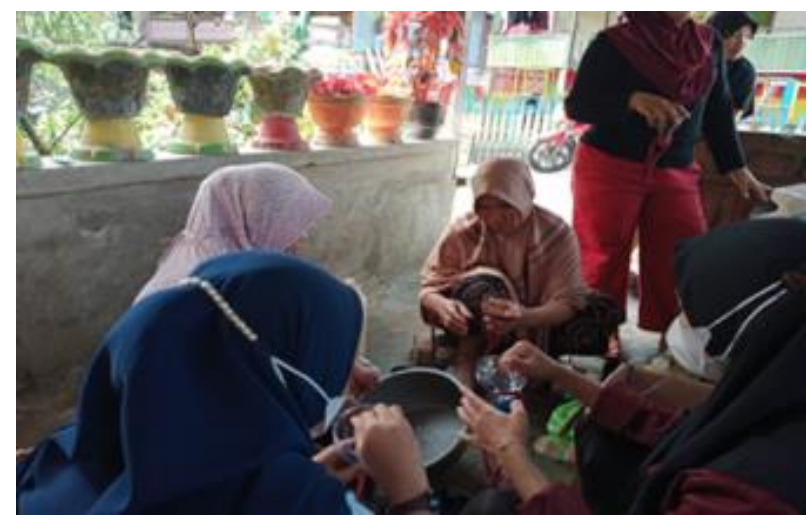

Gambar 3. Penyiapan instalasi hidroponik oleh kelompok tani 
b. Penggilingan sabut kelapa menjadi cocopeat

Sabut dipilih dari buah kelapa yang sudah tua atau matang. Untuk menghilangkan senyawa kimia pada sabut kelapa, perlu direndam terlebih dahulu selama kurang lebih satu minggu dengan mengganti air rendaman secara berkala karena kandungan zat tannin dapat menghambat pertumbuhan tanaman Kandungan senyawa kimia tersebut ditandai dengan munculnya warna merah bata saat sekam direndam dalam air. Selanjutnya adalah membuat sabut kelapa menjadi serbuk dengan menggunakan mesin penggiling. Serbuk tersebut dijemur selama 1-3 hari atau hingga kadar air kurang dari $15 \%$. Apabila kadar air sudah berada di bawah angka $15 \%$, langkah selanjutnya adalah proses pengayakan.

Mitra memahami dan menerapkan metode pengelolaan limbah sabut kelapa yang ramah lingkungan, mudah didapatkan, tidak membutuhkan biaya tamabahan yang besar dan tentunya berkelanjutan. Sejalan dengan manfaat sabut kelapa dari penelitian Hasriani,et al (2013) bahwa media serbuk sabut kelapa memiliki daya simpan air yang tinggi dibandingkan media tanah dan media campuran serbuk sabut kelapa dan tanah. Serbuk sabut kelapa memiliki kadar air dan daya simpan air masing-masing $119 \%$ dan $695,4 \%$.

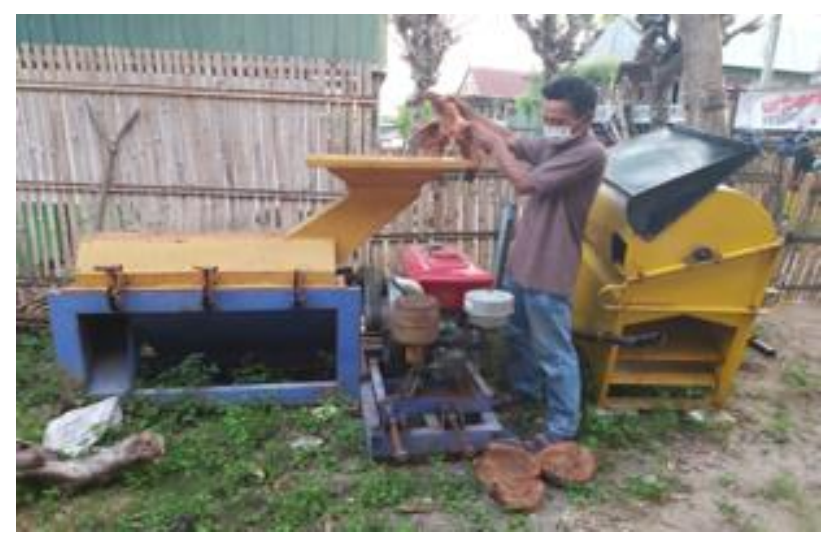

Gambar 4. Penyiapan dan penggilingan sabut kelapa menjadi cocopeat

c. Penyiapan larutan nutrisi AB-Mix

Menyiapakan air $990 \mathrm{ml}$ lalu menambahkan stock A (5 ml) dan stock B (5 ml) menggunakan suntik sehingga larutan menjadi $1 \mathrm{~L}$ begitu pun dengan kelipatan jumlah volume yang dibutuhkan sesuai kebutuhan wadah hidroponik yang diinginkan.

3. Budidaya dan perawatan

Pembibitan tanaman sayuran dilakukan dengan menyemaikan benih tanaman selada, sawi dan kangkung menggunakan media cocopeat dalam wadah yang bagian bawahnya dilubangi beberapa titik. Setelah media tanam yaitu cocopeat dimasukkan, bibit tanaman disemai dengan memberikan jarak sekitar $2 \mathrm{~cm}$. Wadah yang berisi semaian ditempatkan di ruangan gelap atau 
yang tidak terkena sinar matahari. Setelah sekitar 3 hari sampai seminggu, diperiksa kembali apabila sudah ada 2-3 helai daun yang muncul maka dipindahkan ke wadah botol. Pemeriksaan dilakukan secara berkala, pengontrolan nutrisi pada semua wadah, pengendalian hama dan penyakit dilakukan secara mekanik yaitu bila dijumpai ada hama, mengambil dan mematikan hama tersebut dengan cara dipijit. Bila ada tanaman yang terserang penyakit layu, mencabut tanaman dan segera membuang medianya, wadah penanaman dapat digunakan lagi dengan media dan tanaman yang baru dan sehat.

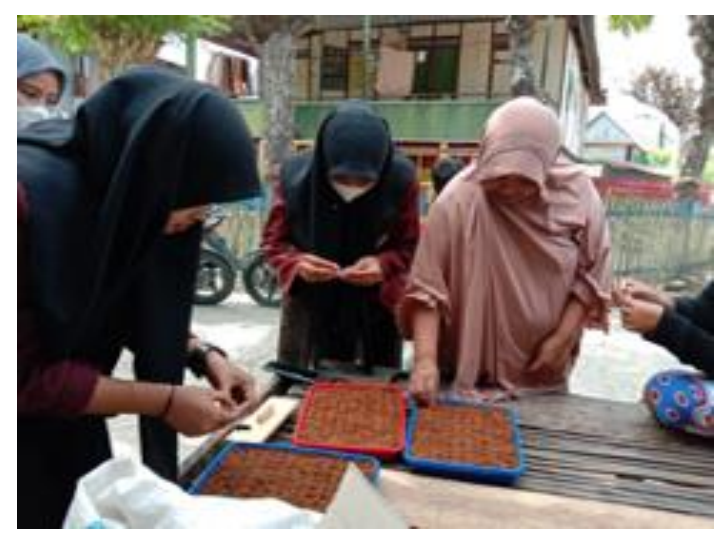

Gambar 5. Budidaya dan perawatan tanaman hidroponik di lahan pekarangan

4. Pemanenan

Kegiatan panen dilakukan setelah tanaman berumur tiga pekan hingga satu bulan. Kangkung yang pertumbuhannya cukup subur dipanen saat berumur 3 pekan. Adapun selada dan sawi dipanen di pekan ke-4 dan ke-5. Beberapa kendala dihadapi kelompok tani sehingga ada beberapa pot yang tidak menunjukkan hasil yang baik, yaitubeberapa semaian dipindahkan agak terlambat ke pot hidroponik, kurang mendapat sinar matahari saat penyemaian dan juga pemindahakan ke pot hidroponik dan kontrol nutrisi yang kurang efektif. Namun, tidak sedikit pula yang menunjukkan hasil panen yang baik dan melimpah. Hal tersebut memberikan semnagat dan kepuasan kelompok tani dari hasil budidaya hidroponiknya.

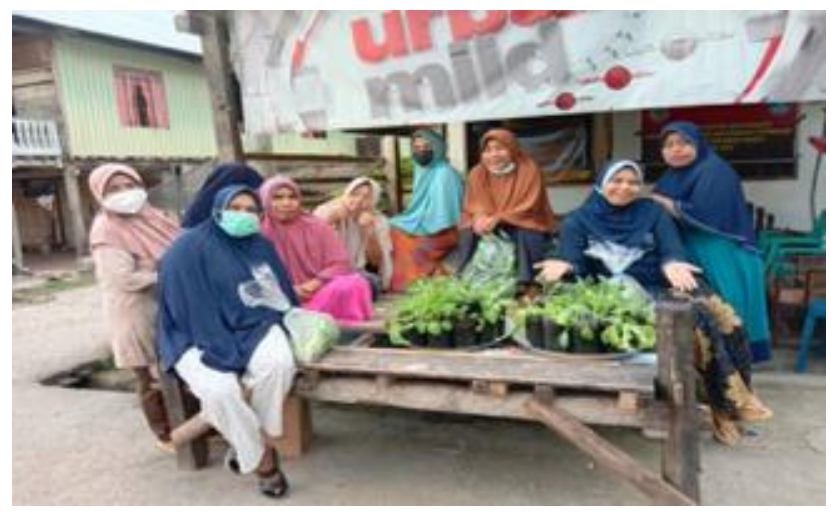

Gambar 6. Hasil Panen Hidroponik

CTo Maega / Jurnal Pengabdian Masyarakat. This is an open access article under the CC BY-SA 4.0 license (https://creativecommons.org/licenses/by-sa/4.0/). 
5. Tinjauan asupan nutrisi dan pendapatan keluarga

Pada 17 Oktober 2021 dilakukan pertemuan kembali untuk penjelasan mengenai aspek kesehatan dan ekonomi yaitu asupan nutrisi sayuran hidroponik dan pendapatan keluarga dari pemanfaatan pekarangan. Kegiatan pengabdian kepada masyarakat ini selain bertujuan untuk mengoptimalkan penggunaan limbah sabut kelapa menjadi cocopeat juga mendukung kegiatan perbaikan gizi keluarga dengan pemanfaatan pekarangan rumah.

Dalam kegiatan ini dijelaskan mengenai keterkaitan gizi dengan imunitas yang mana dijelaskan (Kusmiyati,dkk, 2021) bahwa berbagai aktivitas yang dilakukan masyarakat biasanya terkait dengan menjaga agar imunitas tubuh tetap terjaga dalam menghadapi pandemi covid 19. Menjaga imunitas tubuh tidak terlepas dari pemenuhan gizi sehari-hari. Hal ini sesuai dengan tujuan nasional penyelenggaraan kesehatan, yang bertujuan tercapainya kemampuan untuk hidup sehat bagi setiap penduduk agar dapat mewujudkan derajat kesehatan yang optimal sebagai salah satu unsur kesejahteraan).

Sayuran memiliki banyak manfaat yaitu menurunkan kolesterol jahat, mencegah kanker, memenuhi kebutuhan vitamin, melancarkan proses pencernaan dan meningkatkan metabolisme tubuh. Almatsier (2016) menyatakan bahwa tubuh juga memerlukan serat, serat merupakan bagian dari karbohidrat, yaitu karbohidrat kompleks. Serat tidak dapat dicerna oleh pencernaan tubuh, namun memiliki manfaat untuk melancarkan saluran pencernaan.

Pekarangan juga memiliki potensi untuk dikembangkan sebagai penghasil pangan sekaligus meningkatkan pendapatan keluarga. Produktivitas yang baik dapat mendukung produksi sayuran hidroponik yang apabila dijual dapat mengurangi biaya kebutuhan pangan akan sayuran akan tetapi dapat menambah pendapatan. Sayuran hidroponik yang telah dikemas dapat dijual seharga Rp.10.000,- hingga Rp.15.000 per ikat.

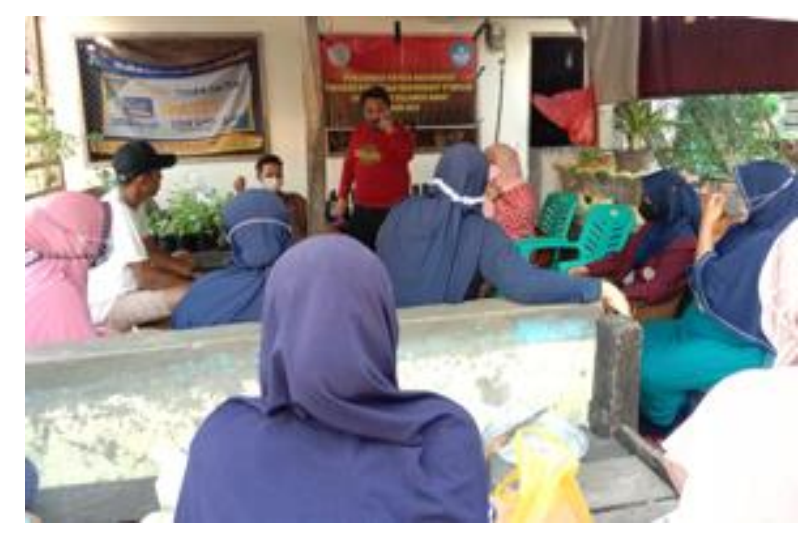

Gambar 7. Penjelasan tim pengabdi mengenai asupan gizi sayuran hidroponik dan upaya peningkatan pendapatan keluarga. 
6. Monitoring dan Evaluasi

Sulistiyawati (2019) menyatakan bahwa monitoring merupakan suatu proses pengawasan untuk melihat perkembangan proses yang direncanakan apakah sesuai dengan prosedur yang sudah ditetapkan atau tidak. Hal ini penting mengingat transfer teknologi dari pengusung ke mitra tidak bisa dilakukan dalam waktu singkat. Sementara itu evaluasi merupakan suatu proses untuk melihat ketercapaian program apakah sesuai dengan tujuan awal program.

Dari hasil monitoring dan evaluasi terindikasi bahwa prosedur sudah diterapkan dalam praktek mitra yaitu Kelompok Tani Posi Lita. Setelah kegiatan dilaksanakan, terjadi peningkatan terhadap pengetahuan tentang budidaya sayuran dengan teknik hidroponik menggunakan limbah sabut kelapa yang diolah menjadi cocopeat.

Hasil pelaksanaan menunjukkan adanya peningkatan kesadaran peserta pelatihan untuk menerapkan sistem hidroponik dan penggunaan media tanam cocopeat untuk meningkatkan pendapatan dan menunjang pemenuhan gizi keluarga. Hal ini terlihat dari antusias para peserta untuk mengaplikasikan hasil pelatihannya dan melanjutkan kegiatan tersebut setelah selesai programnya.

\section{Kesimpulan}

Kegiatan pengabdian ini memberikan solusi dari permasalahan mitra, yaitu dengan adanya pelatihan hidroponik dan pendampingan Kelompok Tani Posi Lita, masyarakat meningkat pengetahuan dan kesadarannya akan pengolahan limbah sabut kelapa menjadi cocopeat yang baik untuk tanaman sayuran hidroponik. Penggunaan cocopeat juga mendukung kelestarian dan ramah lingkungan. Selain mampu meningkatkan pendapatan juga dapat memenuhi kebutuhan gizi keluarga serta menciptakan masyarakat yang sadar lingkungan melalui limbah yang dapat diolah menjadi lebih optimal.

\section{Ucapan Terimakasih}

Ucapan terima kasih disampaikan kepada Hibah DIPA Universitas Sulawesi Barat Tahun 2021 sebagai pemberi dana kegiatan pengabdian program kemitraan masyarakat stimulus ini. Tak lupa pula kepada Kelompok Tani Posi Lita dan segenap warga di Desa Tandung, Kecamatan Tinambung, Kabupaten Polewali Mandar atas partisipasinya sehingga kegiatan ini dapat terlaksana dengan baik.

\section{Daftar Pustaka}

Agustian, A., Friyatno, S., Supadi., Askin, A. (2003). Analisis Pengembangan Agroindustri Komoditas Perkebunan Rakyat (kopi dan kelapa) dalam Mendukung Peningkatan Daya Saing Sektor Pertanian. Makalah Seminar 
[ 53 ] Dwi Ahrisa Putri, dkk / To Maega: Jurnal Pengabdian Masyarakat, Vol.5; No.1; Februari 2022

Hasil Penelitian Pusat Penelitian dan Pengembangan Sosial Ekonomi Pertanian Bogor. T.A.

Almatsier, S. (2016). Prinsip Dasar Ilmu Gizi. Jakarta: PT. Gramedia Pustaka Utama.

Amin., Samidi., Prabandono, K. (2014). Coco Preneurship. Yogyakarta: Lily Publisher.

Balitbang. (2013). Mengenal Participatory Rural Appraisal (PRA). Maluku Utara.

Christina, D. (2019). 'Wick System Hydroponic Gardens'. Diakses dari https://www.thespruce.com/hydroponic- gardens-wick-system-1939222.

Hasriani., Kalsim., D.K., Sukendro, A. (2013). Kajian serbuk sabut kelapa (cocopeat) Sebagai media tanam (study of cocopeat as planting media). Jurnal

Indahyani, \& Titin, (2011). Pemanfaatan Limbah Sabut Kelapa padaprencanaan Interior dan Furniture yang Berdampak padapemberdayaan masyarakat Miskin. Jurnal Humaniora 2 (1): 15-23.

Istomo., \& Valentino, N. (2012). Pengaruh Perlakuan Kombinasi Media Terhadap Pertumbuhan Anakan Tumih (Combretocarpus rotundatus (Miq.) Danser). Jurnal Silvikultur Tropika. 3 (2): 81-84.

Kusmiyati., Rasmi, D.A.C., Khairuddin., Sedijani, P., Handayani. (2021). Penyuluhan Tentang Usaha Perbaikan Gizi Keluarga (UPGK) melalui Pemanfaatan Pekarangan dimasa Pandemi Covid 19. Jurnal Pengabdian IPA. 4(3): 242-247

Orsini, F. (2012). Technical manual, urban vegetable production, Hortis Horticulture in towns for inclusion and socialization (526476-LLP-12012-1, IT GRUNDTVIG-GMP)

Pratiwi, N. E., Bistok H.S., dan Dina, B., (2017). Pengaruh campuran media tanam terhadap pertumbuhan Tanaman stroberi (Fragaria Vesca L.) sebagai tanaman hias Taman vertical. Jurnal Agric (Jurnal Ilmu Pertanian).

Simanjuntak G.P., Heddy, S.Y.B. (2018). Respon Tanaman Horenso (Spinacia Oleraceae L.) terhadap Media Serbuk Sabut Kelapa (COCOPEAT) dan Pupuk cair Kotoran Kelinci. Jurnal Produksi Tanaman. 6(5) : 723 - 728.

Sulistyawati., Muchsin, M., Fatwa T., Surahma, A.M., Tri, W.S. (2019). Pendampingan Pembuatan Sistem Hidroponik dan Pengolahan Sampah Organik. JPPM LPIP UMP. 3(1). 